\title{
СЕМЕЙНАЯ МЕДИАЦИЯ ПО ДЕЛАМ О РАСТОРЖЕНИИ БРАКА В РОССИИ И ЗАРУБЕЖНЫХ СТРАНАХ
}

\author{
(c) 2020 Курмаева Наталья Анатольевна
}

доцент, кандидат юридических наук, доцент кафедры правовых дисциплин

Национальный исследовательский Мордовский государственный университет им. Н.П. Огарёва, Россия, Саранск

Настоящая статья посвящена исследованию особенностей применения медиативной процедуры для урегулирования семейных споров при расторжении брака в таких зарубежных странах, как США, Великобритания, Франция, Германия, Италия. В связи с тем, что в России медиативные технологии не являются достаточно востребованными, для наилучшего урегулирования возникших внутрисемейных проблем на основе анализа зарубежной семейно-медиативной практики необходимо разработать рекомендации по внедрению эффективного опыта зарубежных стран в правовую систему Российской Федерации. Использование посреднических процедур при разрешении семейных споров в США, Великобритании, Франции, Германии, Италии позволяет значительно уменьшить количество гражданских дел в судах, быстро и эффективно разрешить возникшие споры, упростить судебную процедуру и значительно уменьшить судебные расходы по делам о расторжении брака. Богатый опыт альтернативного разрешения семейных споров, накопленный в зарубежных странах, необходимо интегрировать в российскую правовую систему и судебную практику.

Ключевые слова: альтернативное разрешение семейных споров, брак, брачно-семейные споры, медиация, медиатор, процедура примирения, расторжение брака, семья, семейный конфликт, семейная медиация.

Ежегодно в России расторгается значительное количество браков. Например, по данным Федеральной службы государственной статистики в 2018 году зарегистрировано 893039 браков, разводов - 583942, в 2019 году зарегистрировано 950167 браков, разводов - 620730 [1], что составляет $65 \%$ от количества зарегистрированных браков.

Приведенные данные свидетельствуют о том, что расторжение брака является наиболее приемлемым способом разрешения внутрисемейных проблем. При этом нарушаются сложившиеся веками семейные ценности и традиции. Распад семьи, взаимоотчуждение родителей причиняет непоправимый вред нравственному и психическому развитию детей.

Во многих зарубежных странах для наилучшего урегулирования возникших внутрисемейных проблем применяется процедура медиации. Однако в России медиативные технологии не являются достаточно востребованными. На основе анализа зарубежной семейно-медиативной практики необходимо разработать рекомендации по внедрению эффективного опыта зарубежных стран в правовую систему Российской Федерации.
В мировой практике имеется множество примеров успешного применения процедуры медиации при разрешении брачно-семейных споров. При этом в различных странах существуют свои специфические особенности использования медиативных технологий, на которые следует обратить внимание.

В США процедура медиации регламентируется Единообразным Актом о медиации 2001 года [2] и законодательством штатов. Применение данной процедуры позволяет успешно разрешать различные споры, в том числе семейноправовые. При этом медиация может быть как добровольной, так и обязательной. Как правило, семейная медиация проводится по семейнофинансовым делам, связанным с разделом имущества супругов и делам по опеке о распределении прав и обязанностей по воспитанию ребенка [3, С. 94].

Во многих штатах приняты законы, согласно которым проведение семейной медиации обязательно по вопросам опеки и воспитания детей после развода родителей. При судах действуют службы семейной медиации [4, С. 176].

Медиативные технологии получили наибольшее распространение в Калифорнии, Фло-

\footnotetext{
* Исследование выполнено при финансовой поддержке РФФИ в рамках научного проекта № 19-011-00570
} 
риде и Северной Каролине. Например, в штате Северная Каролина для согласования имущественных условий развода и установления прав на опеку и воспитание детей проводится семейная финансовая медиация. Судья направляет супругов в сертифицированные бюро медиации либо их адвокаты нанимают медиаторов. К участию в процессе медиации стороны могут пригласить адвокатов, семейных психологов, социальных работников и финансовых консультантов. Применяется техника «челночной медиации» («shuttle mediation»), которая состоит в том, что супруги находятся со своими адвокатами в разных помещениях, а медиатор работает с каждой из сторон поочередно. Это позволяет избежать проявления негативных эмоций, оскорблений и обид. Дети не участвуют в самом процессе медиации, а их интересы представляет приглашенный детский психолог [5, С. 59].

Возможность разрешения возникшего семейного конфликта на взаимовыгодных для сторон условиях выступает важным преимуществом семейной медиации, а строгое соблюдение конфиденциальности позволяет сохранить в тайне информацию, сообщенную в процессе рассмотрения спора. Еще одной важной особенностью является то, что в процессе медиации не должны рассматриваться дела, связанные с домашним насилием [6, С. 95].

В США функционирует Федеральная служба медиации и примирения [7], издаются журналы по медиации, например, «The American Journal of Mediation» [8].

В отличие от США в Великобритании процедура семейной медиации проводится до судебного разбирательства, что позволяет довольно быстро урегулировать возникший семейный конфликт [9, С. 86]. При этом обращение к медиатору является добровольным. Суды вправе лишь рекомендовать разрешить спор посредством медиации, но не могут обязать стороны участвовать в данной процедуре [10].

Каждой паре, намеренной расторгнуть брак предлагается урегулировать семейный конфликт путем обращения к медиатору. В случае, если супруги желают разрешить спор в судебном порядке, им необходимо мотивировать свое решение. При этом если одна из сторон отказывается от предложения суда пройти процедуру медиации, то на нее возлагаются все судебные расходы, независимо от того, в чью пользу будет вынесено судебное решение [11, С. 270]. Дело о расторжении брака сразу передается на рассмотрение суда только в случаях семейного насилия и для защиты детей.

Информацию о том, куда следует обратиться для проведения процедуры медиации по семейному спору, можно получить по телефону горячей линии. При этом необходимо рассказать о возникшем конфликте, высказать свои предпочтения относительно медиатора, и семейным парам предложат список аккредитованных лиц, предоставляющих медиативные услуги [12, С. 106].

Проведение процедуры медиации в Великобритании финансируется государством, что позволяет семейным парам значительно сэкономить, не прибегая к дорогостоящей судебной процедуре. В то же время с помощью медиатора стороны самостоятельно согласовывают все условия соглашения о расторжении брака, при этом не перекладывая ответственность на судей и адвокатов [13].

Во Франции применяется две формы медиации - частная (внесудебная) медиация и медиация при суде (по направлению суда) [14, С. 113]. Порядок проведения процедуры примирения по делам о расторжении брака регламентируется нормами гражданского и гражданского процессуального законодательства Франции.

Согласно ст. 251 Гражданского кодекса Франции в случае требования развода по причине разлада совместной жизни или виновных действий обязательной является попытка примирения до рассмотрения дела судом. Она может быть повторена и во время судебного рассмотрения [15].

В соответствии со ст. 131-1 Гражданского процессуального кодекса Франции судья, рассматривающий дело, может с согласия сторон назначить посредника для урегулирования взаимных претензий сторон и разрешения возникших между ними разногласий [16].

Таким образом, процедура примирения во Франции, также как и в России, происходит под контролем судьи. Однако в соответствии с законодательством Франции проведение процедуры примирения является обязанностью судьи.

В Германии брачно-семейные споры составляют большую долю конфликтов, разрешаемых посредством участия медиатора. Как правило, при расторжении брака между супругами возникают споры, связанные выполнением условий брачного договора, воспитанием детей, 
установлением опеки, солидарной ответственностью супругов, разделом недвижимого имущества и т.д. [17, С. 86].

Порядок проведения процедуры медиации в Германии регламентируется Законом о медиации от 21 июля 2012 г., в соответствии с которым медиация представляет собой конфиденциальный и структурированный процесс, дающий возможность сторонам при активном содействии одного или нескольких посредников самостоятельно и под свою ответственность прийти к взаимовыгодному урегулированию конфликта [18].

Одной из особенностей процедуры примирения в Германии является то, что медиаторы работают при суде. Это позволяет значительно снизить количество рассматриваемых судами семейных дел. Также в Германии применяется такая процедура примирения, как установление судом периода раздельного проживания супругов для осознания возможности или наоборот невозможности дальнейшего совместного проживания (сепарация) [19].

В Италии порядок проведения процедуры медиации может быть обязательным и добровольным. Обязательная процедура применяет- ся в случаях, прямо предусмотренных законом либо в силу заключенного сторонами соглашения о намерении урегулировать спор в случае его возникновения с участием медиатора [20, С. 295].

Размер пошлины, взимаемый службами медиации регулируется Министерством юстиции Италии, а для лиц, имеющих право на бесплатную юридическую помощь, услуги медиатора предоставляются бесплатно [21, С. 38]. Законодательством Италии предусмотрено получение налогового вычета в случае заключения медиативного соглашения [22, С. 60].

Таким образом, благодаря использованию посреднических процедур при разрешении семейных споров в США, Великобритании, Франции, Германии, Италии удается значительно уменьшить количество гражданских дел в судах, быстро и эффективно разрешить возникшие споры, упростить судебную процедуру, значительно уменьшить судебные расходы и сохранить психическое здоровье членов семьи. Богатый опыт, накопленный в зарубежных странах в сфере альтернативного разрешения семейных споров, необходимо интегрировать в российскую правовую систему и судебную практику.

\section{Библиографический список}

1. Официальный сайт Федеральной службы государственной статистики. URL: https://www.gks.ru/folder/12781 (дата обращения: 25.08.2020).

2. Ресурсный Центр медиации. Единообразный Акт о медиации 2001 года. URL: http://mediators.ru/rus/about_ mediation/foreign_law/usa/text1 (дата обращения: 25.08.2020).

3. Таранова Т. С. Применение медиации по делам, находящимся в суде в США// Актуальные проблемы современного права: сборник научных трудов. Хабаровск, 2016. С. 93-99.

4. Ковальская A.E., Мосиенко Т.А. Сравнительный анализ института примирения при расторжении брака в России и за рубежом // Современная юриспруденция: актуальные вопросы, достижения и инновации: сборник статей III Международной научно-практической конференции: в 2 ч. Пенза, 2017. С. $175-177$.

5. Джанашиа А. 3. Основные направления практики медиации в США// Веснік МДУ імя А.А. Куляшова. Серыя С. Псіхолага-педагагічныя навукі. 2015. № 1 (45). С. 57-62.

6. Таранова Т. С. Указ соч.

7. Federal Mediation \& Conciliation Service. URL: https://www.fmcs.gov/ (дата обращения: 25.08.2020).

8. The American Journal of Mediation. URL: http://www.americanjournalofmediation.com/pg1.cfm (дата обращения: 25.08.2020).

9. Иванова М.С. Использование элементов медиации при расторжении брака в административном и судебном порядке по законодательству зарубежных стран // Вестник Московского университета МВД России. 2011. № 9. С. 83-87.

10. Официальный сайт ФГБУ «Федеральный институт медиации». URL: http://fedim.ru/mediatsiya-v-mire/ evropa/velikobritaniya/ (дата обращения: 25.08.2020).

11. Коломытцева В.В. Этапы становления медиации в зарубежных странах // Вестник Тамбовского университета. Серия: Гуманитарные науки. 2013. № 2 (118). С. 268-272.

12. Избасарова А.Б., Куатова А. А., Амангелдыкызы А., Еренова В. М. Развитие института медиации за рубежом // Наука и мир. 2015. Т. 1. № 3 (19). С. 105-106. 
13. Семейных юристов лишают доходов. В Британии применение медиации при разводах снизило расходы сторон в 5 раз. URL: https://pravo.ru/interpravo/news/view/67090/ (дата обращения: 25.08.2020).

14. Федоренко Н.В., Колесник В. В. Институт медиации в зарубежных странах // Наука и образование: хозяйство и экономика; предпринимательство; право и управление. 2019. № 12 (115). С. 109-113.

15. Российский правовой портал: Библиотека Пашкова. Гражданский кодекс Франции. URL: https://constitutions. $\mathrm{ru} /$ ?cat=275 (дата обращения: 25.08.2020).

16. Новый Гражданский процессуальный кодекс Франции / пер. с франц. В.Захватаев / отв. ред. А.Довгерт. К., 2004. 544 c. URL: https://lawbook.online/protsess-zarubejnyih-grajdanskiy/titul-bis-posrednichestvo-56569. html (дата обращения: 25.08.2020).

17. Иванова М. С. Указ соч.

18. Mediationsgesetz vom 21. Juli 2012 (BGBl. I S. 1577). URL: https://new-advocat.ru/zakon-o-mediacii-v-germanii/ (дата обращения: 25.08.2020).

19. Ковальская А.Е., Мосиенко Т. А. Указ соч.

20. Колосов А.В., Лабыгина Ю.А. Сравнительный анализ процедуры медиации: на примере стран-членов Европейского союза Италии и Германии // Поколение будущего: Взгляд молодых ученых-2017. Сборник научных статей 6-й Международной молодежной научной конференции. В 4-х томах / Отв. ред. А.А. Горохов. Курск, 2017. С. 295-297.

21. Филатова У.Б. Правовое регулирование медиации в иностранных правопорядках: современное состояние и тенденции развития // Вестник федерального института медиации. 2017. № 3. С. 35-41.

22. Загайнова С.К., Чудиновская Н.А., Шереметова Г. С. Обязательная медиация в Италии: проблемы реализации // Электронное приложение к Российскому юридическому журналу. 2017. № 6. С. 56-62. 